\title{
Analisis Index Overlay Untuk Pemetaan Kawasan Berpotensi Banjir di Gowa, Provinsi Sulawesi Selatan
}

\author{
Tectona Putra Epriyan Pratama ${ }^{1 *}$, Supardi ${ }^{1}$, Winona Putri Prihadita ${ }^{1}$, Sebrina Putri Ramadhani ${ }^{1}$, \\ Vivi Putri Yuliatama ${ }^{1}$, Wulan Safitri ${ }^{1}$, Hendun Naura Syifa ${ }^{2}$ \\ ${ }^{1}$ Jurusan Teknik Geofisika, Fakultas Teknik, Universitas Lampung, Jl. Prof. Dr. Ir. Sumantri Brojonegoro, Bandar Lampung, \\ Lampung 35141 \\ ${ }^{2}$ Program Studi Geofisika, Fakultas Matematika dan IImu Pengetahuan Alam, Universitas Indonesia, Jl. Margonda Raya, Kota \\ Depok, Jawa Barat 16424
}

Dikirim:
10 April 2020
Direvisi:
5 Mei 2020
Diterima:
7 Mei 2020
*Email Korespondensi:
epriyanpratma@gmail.com
A cc) (i) @

Abstrak: Pada awal tahun 2019 Kabupaten Gowa dilanda bencana banjir yang menelan korban jiwa, akibat dari hujan dengan intensitas tinggi yang terus melanda kabupaten ini. Berdasarkan hal tersebut maka penelitian ini dilakukan dengan tujuan untuk mengetahui kawasan rawan banjir pada Kabupaten Gowa, Provinsi Sulawesi Selatan dan mengantisipasi dampak dari bencana banjir, baik untuk respons darurat, pemulihan setelah bencana, penetapan strategi untuk mitigasi bencana, serta perancangan penggunaan lahan yang dapat menyimpan air dan menggabungkannya dengan pembangunan berkelanjutan. Dalam penentuan parameter banjir digunakan metode Analisis Weighted Scorring pada Data curah hujan rata-rata bulanan tahun 2012-2019, DEM SRTM wilayah Kabupaten Gowa, Provinsi Sulawesi Selatan, dan peta wilayah Kabupaten Gowa, Provinsi Sulawesi Selatan, yang kemudian dapat digunakan untuk menghitung, mengetahui dan menentukan tingkatan serta parameter-parameter kerentanan banjir serta dapat dilakukan analisis untuk menentukan tingkat kerawanan banjir yang menghasilkan model klasifikasi tingkat kerawanan banjir. Sehingga akan dihasilkan peta mengenai potensi bencana banjir pada wilayah penelitian. Di mana hasil dari penelitian ini menunjukkan bahwa daerah Gowa memiliki kelas lereng datar, dengan kelas drainase buruk- sangat buruk, kemudian tutupan lahan merupakan sawah dan juga pemukiman dengan curah hujan tahunan sebesar 2000-2900 mm/thn.

Kata kunci: banjir, drainase, index overlay, pemetaan, weighted scorring

Abstract: The beginning of 2019, the district was hit by a flood that struck casualties, originating from the highintensity district that continues to hit the district. Based on this, this research was conducted with the aim of studying flood-prone areas in Gowa Regency, South Sulawesi Province and discussing the effects of flood disasters, both for emergency response, recovering after a disaster, setting strategies for disaster mitigation, and designing land use that can store water and savings with sustainable development. In determining the flood parameters the Weighted Assessment Analysis method is used in the 2012-2019 monthly average rainfall data, DEM SRTM in Gowa Regency, South Sulawesi Province, and a map in the Gowa Regency area, South Sulawesi Province, which can then be used for use, searching and determining the level and parameters of flood assessment can be analyzed to determine the level of flooding which results in a flood level classification model. Will produce a map of the potential for flooding in the study area. Where the results of this study indicate that the Gowa area has a flat slope class, with a bad-very bad drainage class, then the land cover represents rice fields and also settlements with rainfall of 2000-2900 $\mathrm{mm} / \mathrm{yr}$.

Keywords: drainage, flood, index overlay, mapping, weighted scorring

\section{PENDAHULUAN}

Banjir merupakan salah satu bencana alam yang banyak terjadi di Indonesia akhir-akhir ini, terutama di saat musim penghujan Bencana ini tidak mengenal wilayah perkotaan ataupun pedesaan dan tentunya memakan banyak kerugian material maupun korban jiwa. Penyebab bencana ini tak hanya disebabkan oleh manusia yang kerap kali mengalih fungsikan daerah yang seharusnya dapat meresap air menjadi lahan perkebunan, pertanian bahkan lahan perindustrian, namun selain itu ada beberapa faktor alam yang dapat menimbulkan banjir, seperti kelerengan di suatu daerah dan juga kemampuan tanah dalam menyerap air hujan.

Daerah dataran banjir adalah daerah dataran rendah di sisi sungai yang memiliki elevasi sangat landai dan relatif datar. Aliran air menuju sungai yang lambat akibat dataran banjir ini, mengakibatkan daerah tersebut rawan terhadap banjir baik oleh luapan air sungai maupun karena hujan lokal.
Bencana banjir umumnya terjadi terutama pada daerah yang dilalui sungai besar dengan debit banjir yang besar (Martha. 2011). Kabupaten Gowa, Sulawesi selatan, dengan luas daerah $1.883,32 \mathrm{~km}^{2}$ serta jumlah penduduk sebanyak 752.896 jiwa dengan persebaran penduduk 400 jiwa $/ \mathrm{km}^{2}$. Berdasarkan total luas wilayah Kabupaten Gowa, sebanyak $35,30 \%$ mempunyai kemiringan tanah di atas $40^{\circ}$, dan $35,06 \%$ dengan kemiringan tanah di atas $40^{\circ}$ yaitu pada wilayah Kecamatan Parangloe, Tinggimoncong, Bungaya serta Tompobolu. Kabupaten Gowa dilalui oleh sungai-sungai yang diketahui cukup besar berkisar lima belas sungai. Sungai dengan luas daerah aliran paling besar adalah sungai Jeneberang dengan luas aliran 881 $\mathrm{km}^{2}$ serta Panjang sungai $90 \mathrm{Km}$. Oleh karena itu, adanya daerah aliran sungai atau DAS di wilayah ini, ditambah lagi dengan Kabupaten Gowa di bagian utara memiliki tingkat kelas curah hujan paling tinggi antara $70-80 \mathrm{~mm} / \mathrm{bln}$ dengan daerah Available online at https://jgrs.eng.unila.ac.id/ DOI: https://doi.org/10.23960/igrs.2020.v1i1.26 
cakupan paling luas di bandingkan dengan daerah lain perlu diketahui daerah mana yang memiliki kerawanan terhadap bencana banjir.

Sistem Informasi Geografis sangat berguna bagi suatu cakupan luas perusahaan swasta dan pemerintah untuk menjelaskan peristiwa, meramalkan hasil, dan strategi perencanaan (Suhardiman, 2012). Untuk itu dengan menggunakan sistem informasi grafis (SIG) maka kita dapat mempermudah mengidentifikasi daerah yang memiliki kerentanan akan bencana banjir lebih besar dari daerah lainnya di Kabupaten Gowa ini menggunakan beberapa parameter penyebab banjir seperti peta kelas ketinggian, kelas lereng, kelas drainase, bentuk lahan, tutupan lahan dan juga curah hujan. Dengan menggunakan metode overlay atau tumpang susun, kerawanan banjir dapat diidentifikasi secara cepat, mudah dan akurat karena metode ini merupakan penyatuan lebih dari satu peta sehingga nantinya menghasilkan peta dengan atribut dari beberapa peta tersebut. Oleh karena itu nantinya hasil dari penelitian ini penting untuk mengetahui tingkat kerawanan bencana banjir di Kabupaten Gowa

\section{TINJAUAN PUSTAKA \\ 2.1 Banjir}

Banjir merupakan salah satu fenomena alam yang sering kali terjadi di dalam kawasan dengan aliran sungai yang banyak. Banjir dapat berupa daerah yang berair pada area yang biasanya kering seperti pada area permukiman dan pusat kota. Banjir juga dapat terjadi disebabkan oleh debit atau volume air yang mengalir pada aliran sungai atau drainase melampaui atau di atas kapasitas pengalirannya. Luapan air tidak menjadi permasalahan apabila tidak menimbulkan kerugian, korban meninggal atau luka-luka, tidak merendam pemukiman dalam kurun waktu yang cukup lama, tidak menimbulkan persoalan bagi kehidupan sehari-hari. Apabila genangan air terjadi cukup tinggi, dalam kurun waktu cukup lama, serta dengan intensitas sering maka hal tersebut akan mengganggu aktivitas manusia. Dalam satu dekade terakhir ini, luas daerah serta frekuensi banjir semakin meningkat dengan kerugian yang semakin besar pula (BNPB, 2013).

Terjadinya banjir dapat disebabkan oleh situasi dan fenomena alam (topografi, curah hujan), kondisi geografis daerah serta aktivitas manusia yang berdampak pada perubahan tata guna ruang dan lahan di suatu wilayah. Banjir di sebagian wilayah Indonesia biasanya terjadi antara Januari hingga Februari, hal ini diakibatkan intensitas curah hujan yang sangat tinggi, seperti intensitas curah hujan DKI Jakarta yang >500 mm (BMKG, 2013). Tata guna lahan dapat didefinisikan sebagai lahan yang dimanfaatkan oleh manusia. Penggunaan lahan biasanya sebagai taman, kehutanan, sarana peternakan dan lahan pertanian (Weng, 2010). Kodoatie dkk. (2006) menjelaskan faktor penyebab banjir antara lain perubahan penggunaan lahan, pembuangan sampah sembarangan, erosi dan sedimentasi, Kawasan kumuh di sepanjang aliran sungai, sistem pengendalian banjir yang kurang tepat, curah hujan tinggi, genesis dan evolusi bentuk sungai, kapasitas sungai yang tidak memadai, pengaruh tidal, penurunan tanah, rusaknya bangunan pengendali banjir. Berdasarkan kondisi geografisnya, wilayah yang terletak di daerah dataran banjir memiliki risiko besar tergenang banjir. Selain Jakarta, terdapat kota-kota besar di Indonesia yang terletak di dataran banjir, sehingga memiliki risiko besar untuk tergenang banjir. Sebanyak tiga belas sungai di Indonesia berpotensi mengalami banjir (Bisnis Indonesia, 2012). Banjir juga dipengaruhi oleh kegiatan manusia serta pembangunan infrastruktur yang kurang mengamati kaidah-kaidah konservasi lingkungan. Banyak pemanfaatan tata ruang yang kurang memperhatikan kemampuan dan juga melebihi kapasitas daya dukungnya. Di wilayah perkotaan, luas ruang terbuka hijau serta taman kota beberapa masih di bawah luas yang ideal untuk sebuah ruang terbuka hijau dan taman kota, kini semakin berkurang dan terdesak oleh pemukiman ataupun digunakan untuk hal lain yang dianggap mampu memberikan keuntungan dalam sektor ekonomi yang lebih tinggi.

\subsection{Sistem Informasi Geografis}

SIG merupakan suatu sistem terkait informasi yang lebih menekankan pada bagian "informasi geografis". Istilah informasi geografis memiliki pengertian informasi mengenai tempat-tempat di permukaan bumi, dan informasi terkait keterangan (atribut) di permukaan bumi yang posisinya diketahui. SIG membantu manusia dalam memahami konsep "dunia nyata" dengan melakukan manipulasi dan persentase data yang direalisasikan terhadap lokasi-lokasi geografis di permukaan bumi. Data geospasial dapat dibedakan menjadi data geometris atau bisa disebut data grafis dan data tematik atau data atribut. Data grafis mempunyai tiga penyusun, yaitu titik (node), garis (arc) serta area (poligon) dalam bentuk vektor maupun raster yang mewakili geometri, pengkajian tempat, ukuran, bentuk, posisi dan arah. Dalam data grafis terdapat dua macam data, yaitu data spasial dan data atribut. Sub sistem manipulasi dan analisis data berfungsi untuk mengarsipkan, menimbun, menarik kembali data primer serta menganalisis data yang telah ada dalam komputer. Sub sistem output data memiliki fungsi untuk menayangkan informasi geografis sebagai hasil dari analisis data dalam proses SIG. Informasi tersebut ditampilkan dalam bentuk peta, tabel bagan, grafik, gambar dan hasil perhitungan (Manongga, 2010).

\subsection{Aplikasi Penginderaan Jarak Jauh dan SIG untuk Pemetaan Kerawanan Banjir}

Penggunaan lahan yaitu fungsi lahan dengan segala campur tangan manusia, baik itu untuk jangka panjang maupun jangka pendek terhadap suatu kelompok sumber daya alam dan sumber daya buatan untuk memenuhi keperluan manusia 
(Malingreau, 1977). Penggunaan lahan sangat penting apabila terkait bentuk pemetaan secara tematik karena pengaruh dua arahnya secara langsung terhadap kehidupan manusia. Variasi dan perubahan yang cukup cepat menjadikan tataguna lahan menjadi parameter yang perlu untuk diperhatikan. Peta kerawanan banjir dibuat dengan menggunakan metode Analytical Hierarchy Process dan Spatial Multi-Criteria Evaluation dengan menggunakan perangkat lunak ILWIS 3.3. Parameter yang digunakan yaitu kemiringan lereng kabupaten Gowa, curah hujan wilayah, bentuk lahan Kabupaten Gowa, dan tataguna lahan. Parameter tersebut merupakan aspek-aspek yang dianggap sangat berpengaruh bagi kerawanan banjir. Analytical Hierarchy Process merupakan salah satu metode pembobotan yang sangat rinci, terstruktur, dan matematis yang digunakan untuk memecahkan permasalahan kompleks dengan menyusun hierarki pembobotan mulai dari subparameter secara terstruktur (Rai dkk., 2004). Setiap sub-parameter dipertimbangkan tingkat hubungan dan pengaruhnya kepada kerentanan banjir. Parameter yang ditentukan juga dibobot dengan metode yang sama pula untuk menentukan parameter yang sekiranya paling berpengaruh terhadap kerawanan banjir.

\subsection{Kriteria Parameter Kerawanan Banjir}

1. Kemiringan Lahan / Kelerengan

Kelerengan atau kemiringan lahan merupakan perbandingan persentase antara jarak vertikal (tinggi lahan) dengan jarak horizontal (panjang lahan datar). Semakin landai kemiringan lerengnya maka semakin berpotensi mengalami banjir, begitu pula sebaliknya. Semakin terjal kemiringannya, maka semakin aman akan bencana banjir.

\section{Ketinggian Lahan/Elevasi}

Ketinggian (elevasi) lahan adalah ukuran tinggi daerah di atas permukaan laut. Ketinggian dapat mempengaruhi terjadinya banjir. Semakin rendah suatu daerah maka semakin berpotensi mengalami banjir, begitu pula sebaliknya. Semakin tinggi suatu daerah, maka semakin aman akan bencana banjir.

\section{Jenis Tanah}

Jenis tanah pada suatu daerah sangat berpengaruh dalam proses penyerapan air atau yang biasa kita sebut sebagai proses infiltrasi. Infiltrasi adalah proses aliran air di dalam tanah secara vertikal akibat adanya potensial gravitasi. Secara fisik terdapat beberapa faktor yang mempengaruhi infiltrasi seperti jenis tanah, kepadatan tanah, suhu tanah dan vegetasi di atasnya. Laju infiltrasi pada tanah akan semakin kecil dikarenakan kelembaban tanah mengalami peningkatan pula (Harto, 1993). Semakin besar daya serap tanah terhadap air maka semakin kecil pula tingkat kerentanan banjirnya. Begitu pula sebaliknya, Semakin kecil daya serap tanah terhadap air maka semakin besar pula tingkat kerawanan banjirnya (Matondang, J.P., 2013).

\section{Curah Hujan}

Curah hujan merupakan banyaknya air hujan yang turun pada suatu daerah dalam kurun waktu tertentu. Curah hujan rata-rata di seluruh wilayah bersangkutan diperlukan untuk perancangan pengendalian banjir, bukan hanya curah hujan pada suatu titik saja. Curah hujan tersebut biasa disebut curah hujan wilayah/daerah. Semakin tinggi curah hujannya maka semakin berpotensi terjadi banjir, begitu pula sebaliknya. Semakin rendah curah hujannya, maka semakin aman akan bencana banjir.

\section{Penggunaan Lahan}

Penggunaan lahan dapat mempengaruhi kerawanan banjir suatu daerah, tataguna lahan akan berperan pada besarnya air limpasan hasil dari hujan yang telah melampaui laju infiltrasi. Lahan yang banyak ditumbuhi vegetasi maka air hujan akan banyak diserap serta lebih banyak waktu yang dibutuhkan limpasan untuk sampai ke sungai, sehingga kemungkinan terjadinya banjir lebih kecil daripada daerah yang tidak ditanami vegetasi. Kadar bahan organik di kebun di daerah lereng memiliki bobot nilai $<0.9 \mathrm{~g} \mathrm{~cm}^{-3}$, kadar bahan organik tertinggi terdapat di pegunungan hutan sekunder yang di mana daerah tersebut terdapat penumpukan vegetasi paling tinggi dibandingkan daerah lain, vegetasi ini dapat menimbulkan biomassa yang banyak sehingga dapat menghasilkan serasah yang banyak. (Junedi, 2010).

\section{Kerapatan Sungai}

Kerapatan aliran adalah panjang aliran sungai per kilometer persegi luas DAS. Semakin besar nilai kerapatan aliran, semakin baik sistem pengaliran di suatu wilayah artinya, semakin besar jumlah air larian total (semakin kecil daya serap tanah) dan semakin kecil air tanah yang tersimpan di daerah tersebut (Matondang, J.P., 2013).

$$
D d=\sum \frac{L n}{A}
$$

Dengan:

$$
\begin{aligned}
\mathrm{Dd} & =\text { Kerapatan aliran }\left(\mathrm{Km} / \mathrm{Km}^{2}\right) \\
\mathrm{Ln} & =\text { Panjang sungai }(\mathrm{Km}) \\
\mathrm{A} & =\text { Luas DAS }\left(\mathrm{km}^{2}\right)
\end{aligned}
$$

Lynsley (1975) menyatakan bahwa jika nilai kerapatan aliran $<1 \mathrm{mile} / \mathrm{mile}^{2}\left(0,62 \mathrm{Km} / \mathrm{Km}^{2}\right)$, DAS akan mengalami penggenangan, sedangkan apabila nilai kerapatan $>5$ mile/ mile $^{2}\left(3,10 \mathrm{Km} / \mathrm{Km}^{2}\right)$, daerah aliran sungai sering mengalami kekeringan. Lynsley juga berpendapat bahwa ilmu geografi fisik berkaitan dengan ilmu yang mempelajari tentang air di muka bumi dengan sorotan khusus yang ditinjau dari sifat, fenomena dan distribusi air di daratan.

\section{BAHAN DAN METODE PENELITIAN \\ 3.1 Waktu dan Lokasi Penelitian}

Lokasi yang dipilih dalam penelitian ini adalah Kabupaten Gowa, Provinsi Provinsi Sulawesi Selatan (Gambar 1). Penelitian dimulai dari bulan November 2019 sampai Desember 2019 di Gedung 
L Teknik Geofisika, Fakultas Teknik, Universitas Lampung.

Wilayah penelitian adalah wilayah Kabupaten Gowa, Provinsi Sulawesi Selatan. Kabupaten Gowa berada pada $12^{\circ} 38.16^{\prime}$ Bujur Timur dari Jakarta dan $5^{\circ} 33.6$ ' Bujur Timur dari Kutub Utara. Sedangkan letak administrasinya antara $12^{\circ} 33.19^{\prime}$ hingga $13^{\circ} 15.17^{\prime}$ Bujur Timur dan $5^{\circ} 5^{\prime}$ hingga $5^{\circ} 34.7^{\prime}$ Lintang Selatan dari Jakarta. Kabupaten Gowa merupakan daerah otonom, di sebelah utara berbatasan dengan Kota Makassar serta Kota Maros. Di sebelah Timur berbatasan dengan Kabupaten Sinaji, Bulukumba dan Bantaeng. Di sebelah Selatan berbatasan dengan Kabupaten Takalar serta Jeneponto, dan di bagian Baratnya berbatasan dengan Kota Makassar dan Takalar.

Kabupaten Gowa terdiri atas 18 Kecamatan, 46 Kelurahan dan 121 desa. Pada tahun 2017, luas wilayah Kabupaten Gowa adalah 1.883,32 km² dan jumlah penduduk sebanyak 752.896 jiwa dengan persebaran penduduk per wilayah $400 \mathrm{jiwa} / \mathrm{km}^{2}$. Wilayah Kabupaten Gowa sebagian besar merupakan dataran tinggi yaitu sekitar $72,26 \%$. Ada delapan wilayah kecamatan yang merupakan dataran tinggi, yaitu Parangloe, Manuju, Tinggimoncong, Tombolo Pao, Bungaya, Bontolempangan, Tompobulu dan Biringbulu.

Berdasarkan total luas kabupaten Gowa, 35,30 $\%$ dengan kemiringan tanah $>40^{\circ}$, dan $35,06 \%$ dengan kemiringan tanah $>40^{\circ}$ yaitu pada Kecamatan Parangloe, Tinggimoncong, Bungaya dan Tompobolu. Kabupaten Gowa dilalui oleh sungai-sungai yang cukup besar berkisar lima belas sungai. Sungai yang memiliki luas aliran terbesar adalah sungai Jeneberang dengan luas $881 \mathrm{~km}^{2}$ dan Panjang $90 \mathrm{Km}$.
Seperti hal nya dengan daerah lain di Indonesia, di kabupaten Gowa terdapat dua musim, yaitu musim kemarau dan musim penghujan. Biasanya musim kemarau terjadi pada bulan Juni hingga September, sedangkan musim hujan terjadi pada bulan Desember hingga Maret. Hal ini berganti setiap enam bulan setelah masa peralihan, yaitu bulan April-Mei dan Oktober-November

\subsection{Alat dan Bahan}

Peta ini diolah dengan bantuan software ArcGIS 10.3. Bahan yang digunakan untuk penelitian ini antara lain: Data curah hujan rata-rata bulanan tahun 2012-2019, citra Landsat, peta tematik, DEM SRTM wilayah Kabupaten Gowa, Provinsi Sulawesi Selatan, dan peta wilayah Kabupaten Gowa, Provinsi Sulawesi Selatan yang bersumber dari USGS Earth Explorer.

Tabel 1. Sumber Data dan Hasil Pengolahan Peta

\begin{tabular}{|c|c|c|}
\hline No & Data & Hasil \\
\hline 1 & $\begin{array}{l}\text { Data curah hujan } \\
\text { rata-rata bulanan } \\
\text { tahun } 2012-2019\end{array}$ & $\begin{array}{l}\text { Peta curah } \\
\text { hujan bulanan } \\
\text { dan tahunan }\end{array}$ \\
\hline 2 & Citra Landsat & $\begin{array}{l}\text { Peta } \\
\text { Penutupan } \\
\text { lahan }\end{array}$ \\
\hline 3 & $\begin{array}{l}\text { DEM SRTM } \\
\text { Kabupaten Gowa }\end{array}$ & $\begin{array}{l}\text { Peta kelas } \\
\text { lereng }\end{array}$ \\
\hline 4 & Peta tematik & $\begin{array}{l}\text { Peta drainase, } \\
\text { bentuk lahan } \\
\text { dan buffer }\end{array}$ \\
\hline 5. & $\begin{array}{l}\text { Peta wilayah } \\
\text { kabupaten Gowa }\end{array}$ & $\begin{array}{l}\text { Peta wilayah } \\
\text { penelitian }\end{array}$ \\
\hline
\end{tabular}

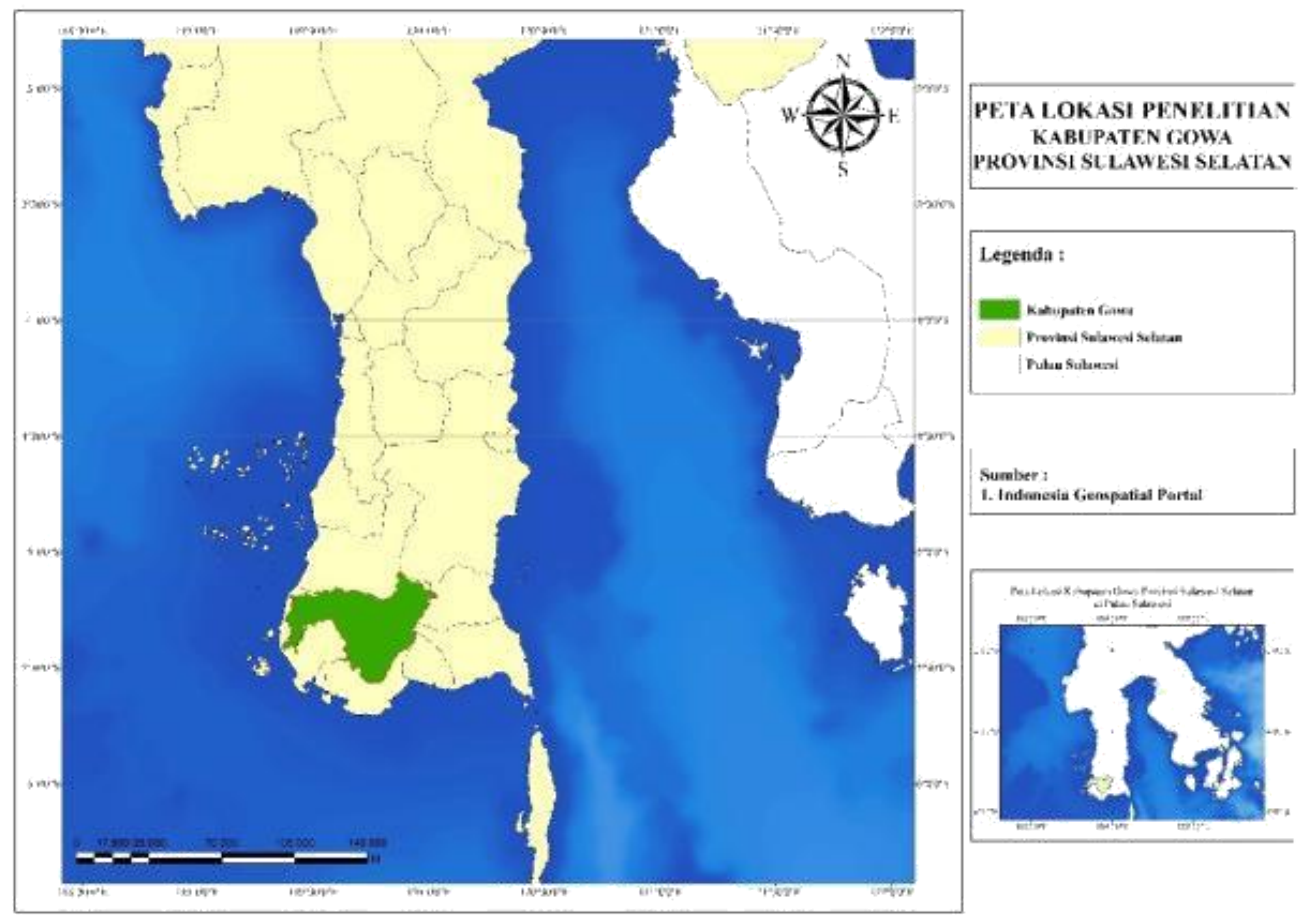

Gambar 1. Peta Lokasi Penelitian Analysis Index Overlay untuk Pemetaan Kawasan Berpotensi Banjir Berbasis SIG 


\subsection{Tahapan Penelitian}

Tahapan penelitian dibagi menjadi beberapa tahapan, yaitu tahap persiapan, pelaksanaan, pengolahan data, analisis dan tahap penyelesaian seperti yang ditunjukkan pada Gambar 2 berikut ini.

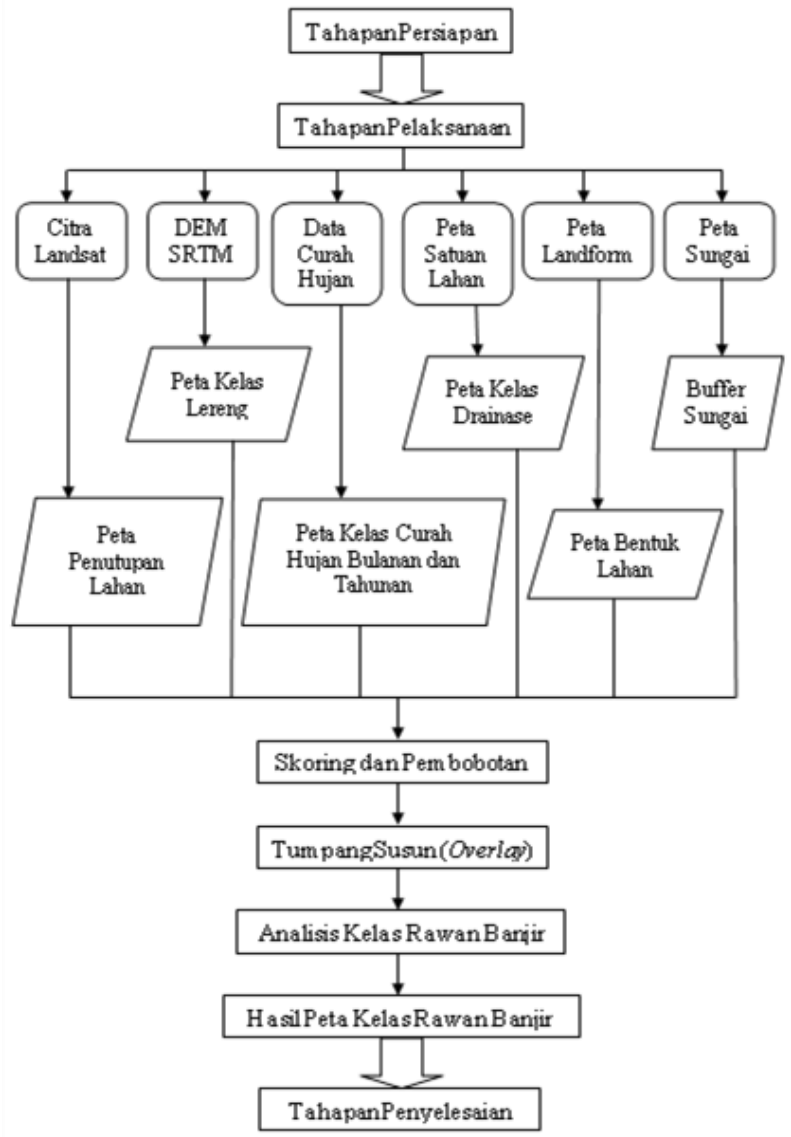

Gambar 2. Tahapan penelitian yang terdiri dari 3 proses utama yaitu tahapan persiapan, tahapan pelaksanaan, dan tahapan penyelesaian.

\section{Tahapan Persiapan}

Untuk melakukan penelitian ini dibutuhkan untuk mempersiapkan Data curah hujan rata-rata bulanan dan tahun 2012-2019, citra Landsat, peta tematik, DEM SRTM wilayah Kabupaten Gowa, Provinsi Sulawesi Selatan, dan peta wilayah Kabupaten Gowa, Provinsi Sulawesi Selatan.

\section{Tahapan Pelaksanaan}

Meliputi pembuatan basis data dan analisis data, seperti pengolahan dan pengindraan jarak jauh berupa interpretasi dan digitalisasi citra Landsat serta pengolahan DEM SRTM.

\section{a. Peta tutupan lahan}

Peta ini diolah dari citra Landsat dengan kombinasi band 5,4 dan 2, yang diolah dengan bantuan software ArcGIS 10.3.

Tabel 2. Pembagian Pembobotan dan Nilai Skor Kelas Penutupan Lahan (Suherlan, 2001)

\begin{tabular}{llcl}
\hline No & $\begin{array}{c}\text { Kelas Penutupan } \\
\text { Lahan }\end{array}$ & Skor & Bobot \\
\hline 1 & Sawah & 100 & \\
2 & Industri & 90 & \\
\hline
\end{tabular}

\begin{tabular}{clcl}
\hline No & $\begin{array}{c}\text { Kelas Penutupan } \\
\text { Lahan }\end{array}$ & Skor & Bobot \\
\hline 3 & Perumahan & 80 & \\
4 & Tanah Berbatu & 70 & \\
5 & Tegalan & 60 & \\
6 & Kebun Campuran & 50 & \\
7 & Perkebunan & 40 & \\
8 & Padang Rumput & 30 & \\
9 & Hutan Sejenis & 20 & \\
10 & Hutan Belukar & 10 & \\
11 & Hutan Lebat & 1 & \\
\hline
\end{tabular}

b. Peta kemiringan lereng.

Peta ini didapat dari pengolahan data DEM SRTM wilayah kabupaten Gowa yang kemudian dikonversikan menjadi slope kemiringan lereng yang setelahnya diberikan klasifikasi dengan batasan nilai sehingga menghasilkan peta kemiringan lereng.

Tabel 3. Pembagian Pembobotan dan Nilai Skor Kelas Kemiringan Lereng (Suherlan, 2001)

\begin{tabular}{clcc}
\hline No & $\begin{array}{c}\text { Kelas } \\
\text { Kemiringan } \\
\text { Lereng }\end{array}$ & Skor & Bobot \\
\hline 1 & Datar $(0-3 \%)$ & 90 & \\
2 & Landai $(3-8 \%)$ & 75 & \\
3 & Agak Curam (8- & 40 & 20 \\
& $15 \%)$ & & \\
4 & Curam (15-25\%) & 20 & \\
5 & Sangat Curam & 1 & \\
& $(25-40 \%)$ & 0 & \\
6 & Terjal $(>40 \%)$ & 0 & \\
\hline
\end{tabular}

c. Peta curah hujan bulanan dan tahunan

Peta ini merupakan hasil dari pengolahan data curah hujan rata-rata bulanan dan tahun 2012-2019 proses ini dilakukan dengan metode interpolasi keruangan menggunakan metode kriging. yang kemudian didapatkan hasil peta curah hujan bulanan dan peta curah hujan tahunan.

Tabel 4. Pembagian Pembobotan dan Nilai Skor Kelas Curah Hujan (Suherlan, 2001)

\begin{tabular}{cccc}
\hline No & $\begin{array}{c}\text { Kelas Curah } \\
\text { Hujan }\end{array}$ & Skor & Bobot \\
\hline 1 & $>450 \mathrm{~mm}$ & 100 & \\
2 & $425-450 \mathrm{~mm}$ & 90 & \\
3 & $400-425 \mathrm{~mm}$ & 80 & \\
4 & $375-400 \mathrm{~mm}$ & 70 & \\
5 & $350-375 \mathrm{~mm}$ & 60 & 30 \\
6 & $325-350 \mathrm{~mm}$ & 50 & \\
7 & $300-325 \mathrm{~mm}$ & 40 & \\
8 & $275-300 \mathrm{~mm}$ & 30 & \\
9 & $250-275 \mathrm{~mm}$ & 20 & \\
10 & $225-250 \mathrm{~mm}$ & 10 & \\
\hline
\end{tabular}




\section{d. Peta bentuk lahan}

Peta ini diolah dari pengolahan peta landform yang kemudian mendapatkan hasil berupa peta bentuk lahan.

Tabel 5. Pembagian Pembobotan dan Nilai Skor Kelas Ketinggian (Suherlan, 2001)

\begin{tabular}{clcc}
\hline No & Kelas Ketinggian & Skor & Bobot \\
\hline 1 & $<500 \mathrm{~m}$ & 100 & \\
2 & $500-1000 \mathrm{~m}$ & 75 & \\
3 & $1000-1500 \mathrm{~m}$ & 50 & 30 \\
4 & $1500-2000 \mathrm{~m}$ & 25 & \\
5 & $>200 \mathrm{~m}$ & 1 & \\
\hline
\end{tabular}

Tabel 6. Pembagian Pembobotan dan Nilai Skor Kelas Tekstur Tanah (Suherlan, 2001)

\begin{tabular}{llcc}
\hline No & $\begin{array}{l}\text { Kelas Tekstur } \\
\text { Tanah }\end{array}$ & Skor & Bobot \\
\hline 1 & Halus & 100 & \\
2 & Sedang & 50 & 10 \\
3 & Kasar & 1 & \\
\hline
\end{tabular}

e. Peta drainase,

Peta ini menggunakan peta satuan lahan yang berdasarkan jenis tanah di daerah penelitian dilakukan klasifikasi drainase.

f. Peta buffer sungai.

Peta ini didapat dari peta sungai yang kemudian dilakukan analisis keruangan yaitu buffer. Yang pada akhirnya menghasilkan daerah dalam lebar tertentu pada peta buffer sungai digambarkan dengan jarak tertentu di sekitar sungai.

\section{g. Analisis atribut}

Analisis atribut dengan pemberian skor untuk masing-masing parameter banjir dan nilai bobot untuk kelas banjir. Pemberian skor dan pembobotan didasarkan pada pengaruh kelas tersebut terhadap kejadian banjir. Yang di mana semakin besar pengaruhnya terhadap kejadian banjir, maka semakin tinggi nilai skornya.

h. Overlay (tumpang susun)

Proses ini dilakukan dengan melakukan overlay pada semua peta yang menjadi parameter yang meliputi peta curah hujan, dan parameter kenampakan wilayah seperti lereng, tanah, bentuk lahan, aliran dan kenampakan sungai serta wilayah penutupan lahan. Selanjutnya dari hasil proses tersebut menghasilkan peta rawan banjir.

3. Tahapan Penyelesaian

Tahap ini untuk mengevaluasi dan validasi hasil identifikasi objek dan analisis, perbaikan peta serta kesesuaian hasil akhir.

\section{KONDISI UMUM WILAYAH PENELITIAN 4.1 Topografi}

Informasi dari ketinggian tempat dan kelas lereng diperoleh dari peta DEM SRTM. Dominan ketinggian pada daerah Gowa adalah -35 sampai 225 yang terdapat di bagian barat Kabupaten Gowa. Selanjutnya juga maksimal ketinggian pada Kabupaten Gowa di kisaran 1.575 sampai 3.642, pada ketinggian tersebut dominan di bagian timur Kabupaten Gowa. Serta untuk ketinggian yang berkisar 225 sampai 511, 511 sampai 916 , dan 916 sampai 1.575 berada di bagian timur Kabupaten Gowa (Gambar 3).

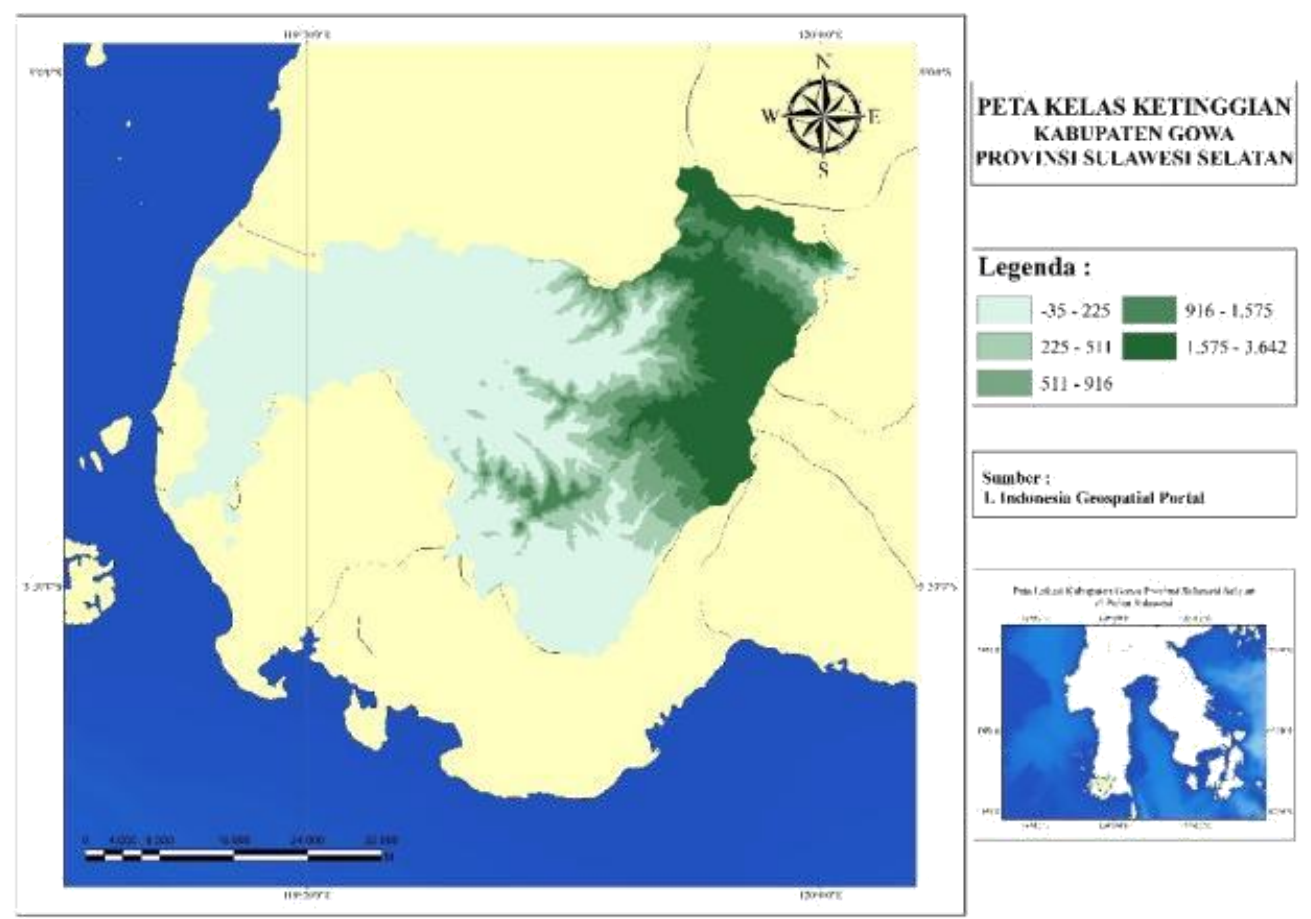

Gambar 3. Peta Topografi Kabupaten Gowa sebagai daerah penelitian Analysis Index Overlay untuk Pemetaan Kawasan Berpotensi Banjir Berbasis SIG. 


\subsection{Lereng}

Kabupaten Gowa Provinsi Sulawesi Selatan memiliki empat kelas lereng. Dalam peta kelas kemiringan lereng yang telah dibuat dapat di lihat bahwa Kabupaten Gowa, Provinsi Sulawesi Selatan dengan memiliki daerah dominan datar hingga datar-berombak. Bagian wilayah barat Kabupaten Gowa, Provinsi Sulawesi Selatan merupakan daerah dengan dominan kelas kemiringan lereng datar (0-3\%), bagian timur hingga selatan merupakan daerah datar-berombak, bergelombang (8$15 \%)$, dan berbukit kecil (15-30\%) (Gambar 4).

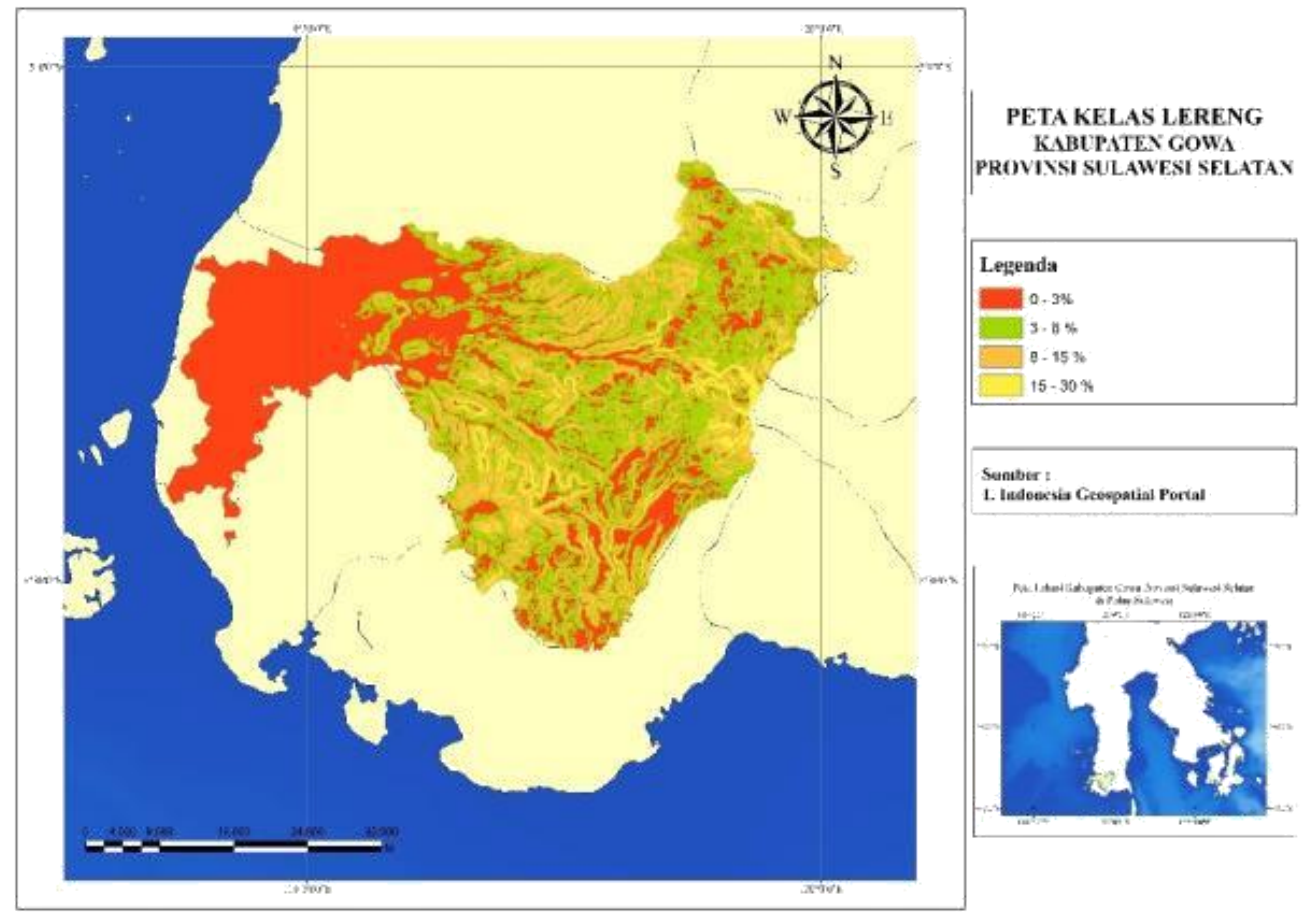

Gambar 4. Peta Lereng Kabupaten Gowa sebagai daerah penelitian Analysis Index Overlay untuk Pemetaan Kawasan Berpotensi Banjir Berbasis SIG

\subsection{Kelas Drainase}

Pada Kabupaten Gowa, Provinsi Sulawesi Selatan terdapat empat kelas drainase. Pada peta yang telah dibuat dapat dilihat bahwa bagian barat
Kabupaten Gowa lebih didominasi dengan kelas drainase sangat buruk dan sebelah timur lebih dominasi kelas drainase baik dan sedang (Gambar 5).

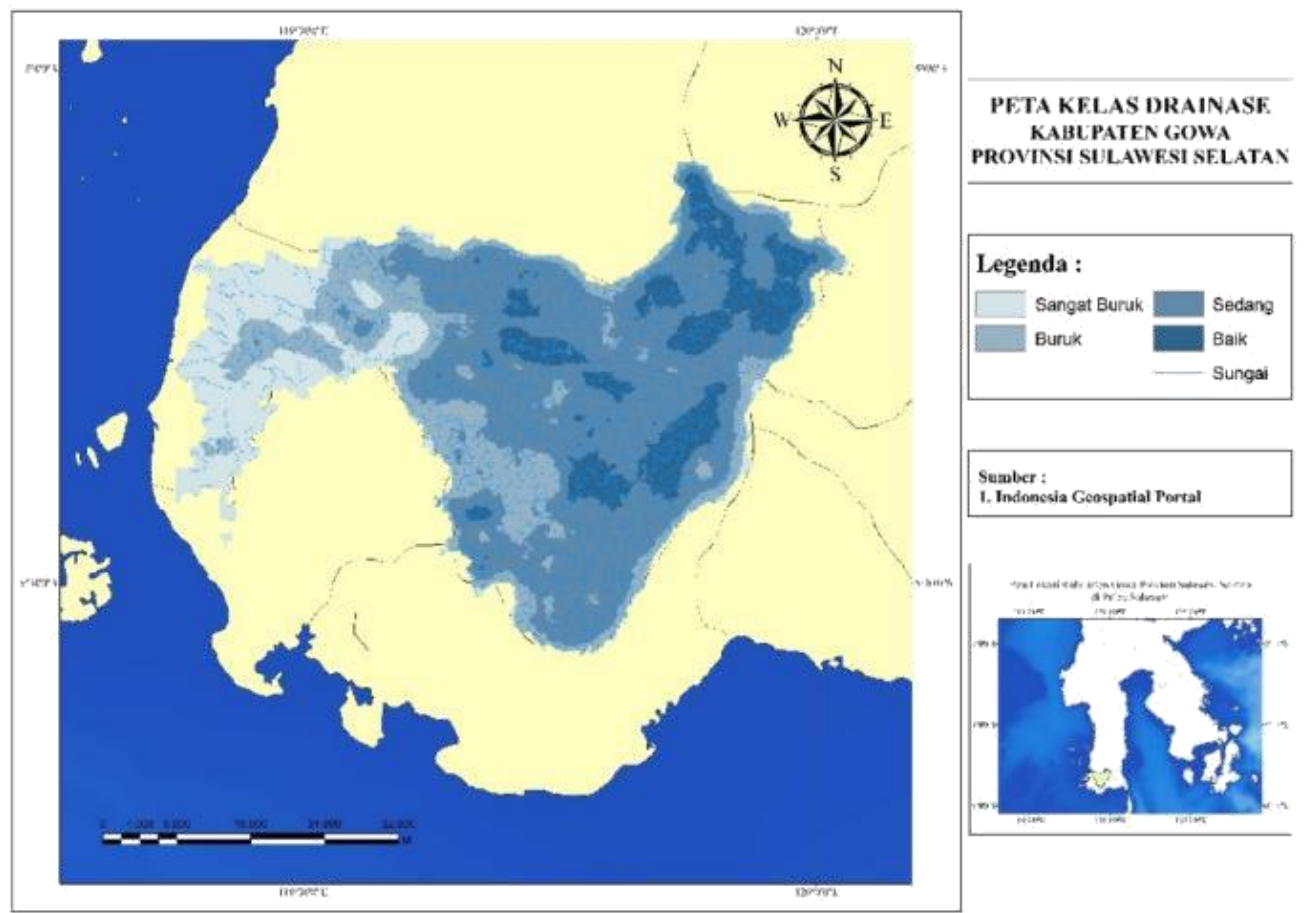

Gambar 5. Peta Kelas Drainase Kabupaten Gowa sebagai daerah penelitian Analysis Index Overlay untuk Pemetaan Kawasan Berpotensi Banjir Berbasis SIG 


\subsection{Buffer Sungai}

Peta sungai didapatkan dari peta primer dan citra landsat yang kemudian dilakukan analisis keruangan yaitu buffer. Zona buffer sungai merupakan daerah dengan lebar tertentu dan di- gambarkan di area sungai dengan jarak tertentu. Zona berwarna biru muda dengan lebar 100-200 m, zona berwarna biru memiliki lebak kurang dari 100 $\mathrm{m}$, dan zona berwarna biru tua memiliki lebar 200500 m (Gambar 6).

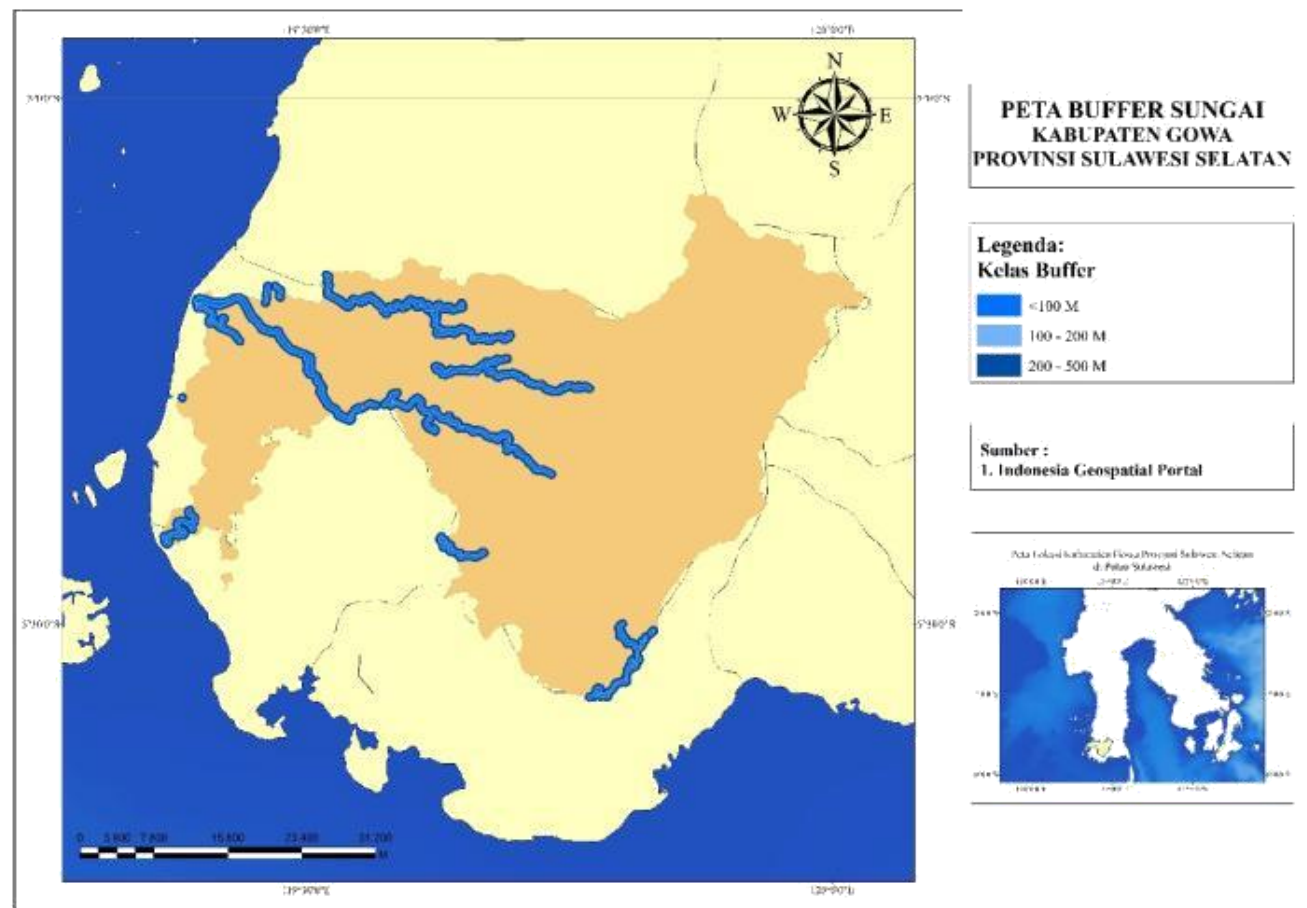

Gambar 6. Buffer Sungai Kabupaten Gowa sebagai daerah penelitian Analysis Index Overlay untuk Pemetaan Kawasan Berpotensi Banjir Berbasis SIG.

\subsection{Bentuk Lahan}

Pada peta tersebut bentuk lahan didapatkan bahwa di Kabupaten Gowa terdapat daerah rawa, sungai dan danau. Untuk mendapatkan peta terse- but dengan menggunakan peta batas administrasi yang didapatkan dari Indonesia Geospasial Portal. Dalam pembuatannya diperlukan juga peta landform dari Provinsi Sulawesi Selatan (Gambar 7).

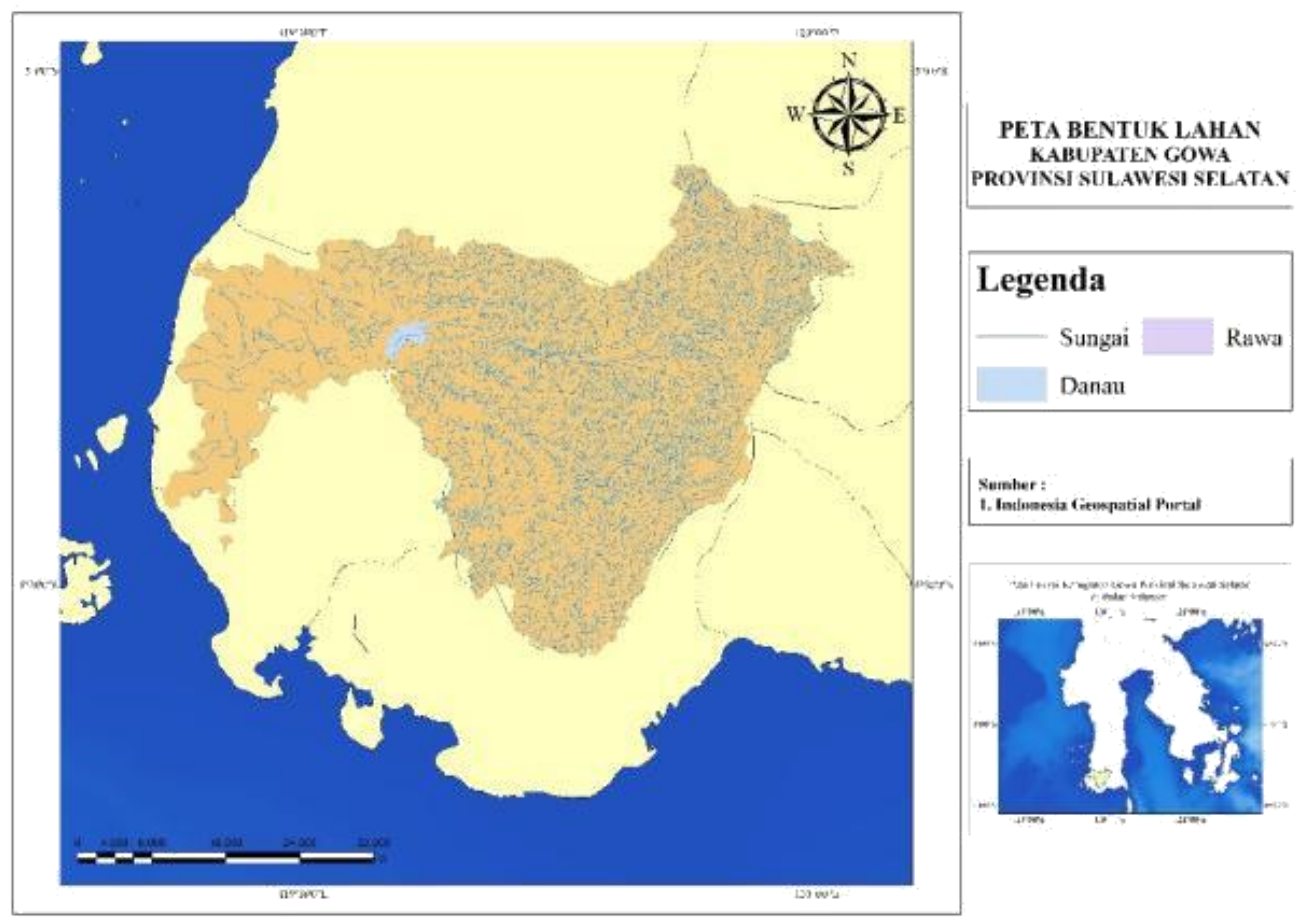

Gambar 7. Peta Bentuk Lahan Kabupaten Gowa sebagai daerah penelitian Analysis Index Overlay untuk Pemetaan Kawasan Berpotensi Banjir Berbasis SIG 
Letak danau terdapat ditengah kabupaten tersebut. Daerah Kabupaten Gowa didominasi oleh daerah sungai yang tersebar secara merata. Persebaran sungai di Kabupaten Gowa juga saling tersambung dan jaraknya sangat berdekatan sehingga aliran sungainya terlihat saling tumpang tindih.

\section{HASIL DAN PEMBAHASAN \\ 5.1 Tutupan Lahan}

Pada peta tersebut penutupan lahan didominasi oleh hutan, kemudian di urutan kedua penutupan lahan yang tersebar di Kabupaten Gowa ialah sawah yang didominasi pada bagian barat Kabupaten Gowa. Selanjutnya disusul oleh tutupan lahan semak. Kemudian tutupan lahan berupa ladang mendominasi di bagian selatan kabupaten gowa. Pemukiman penduduk kebanyak mendiami di daerah barat laut dari Kabupaten Gowa. Selanjutnya terdapat dua daerah tutupan lahan berupa danau. Dan daerah tutupan lahan pasir di sekitar salah satu danau tersebut. Daerah kebun rawa dan tambak memiliki daerah yang sangat kecil pada Kabupaten Gowa (Gambar 8).

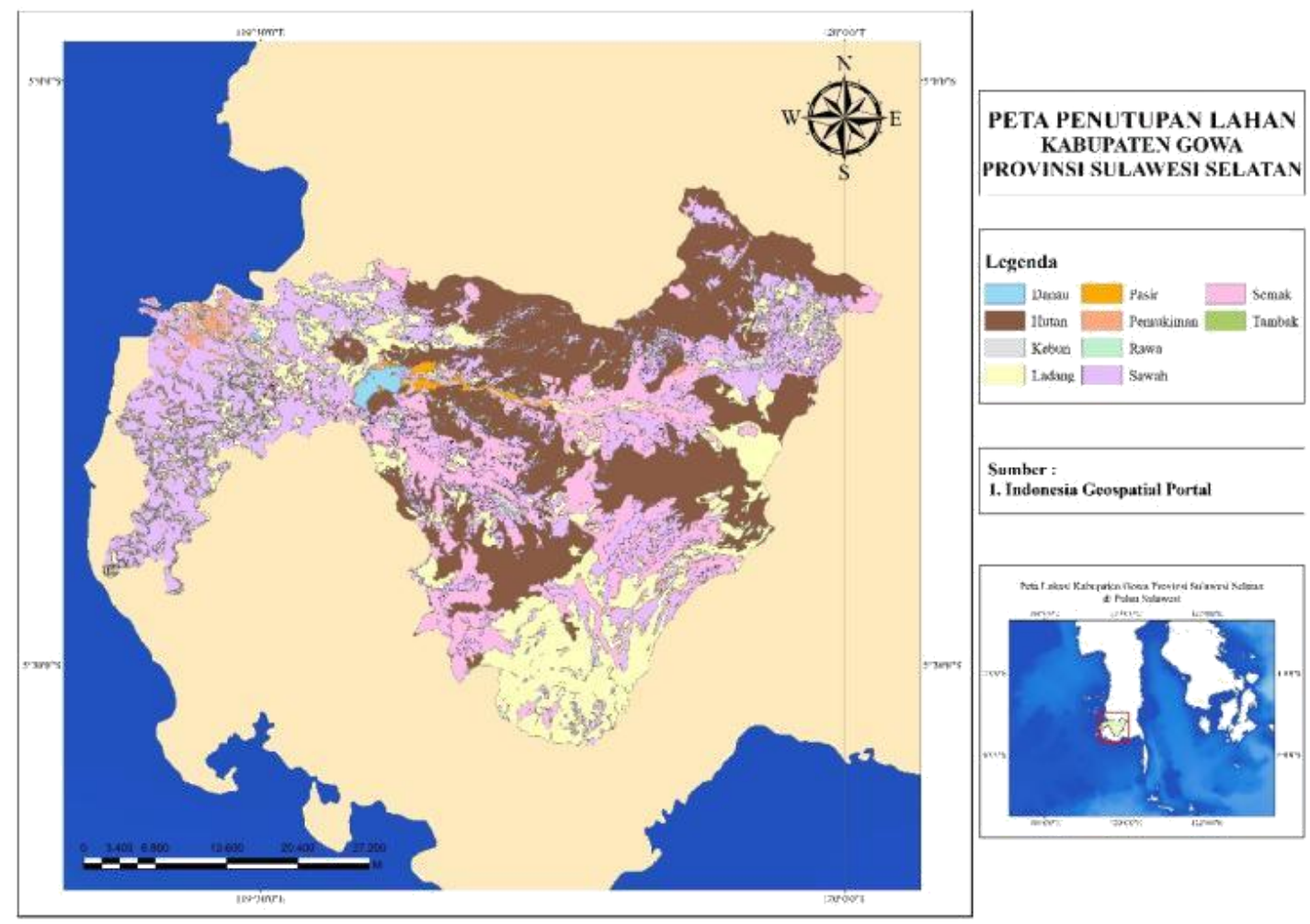

Gambar 8. Peta Penutupan Lahan Kabupaten Gowa sebagai daerah penelitian Analysis Index Overlay untuk Pemetaan Kawasan Berpotensi Banjir Berbasis SIG

\subsection{Curah Hujan Tahunan}

Adapun deskripsi peta curah hujan yang di buat adalah peta curah hujan rata-rata per tahun dan peta curah hujan rata-rata per bulan (dalam tiga bulan puncak selama musim hujan). Kabupaten Gowa Provinsi Sulawesi Selatan termasuk salah satu kabupaten yang memiliki tingkat curah hujan tahunan dalam periode 20 tahun dari setiap stasiun hujan. Pada Kabupaten Gowa sendiri di beda kan menjadi 3 klasifikasi tingkat hujan yaitu: paling tinggi, sedang dan rendah. Berdasarkan peta di atas dapat dilihat bahwa Kabupaten Gowa memiliki tingkat curah hujan yang sedang paling luas dibandingkan dengan yang kering dan sangat kering. Dengan tingkat kelas curah hujan sebesar 2000-2900 mm/thn. Daerah yang kering dengan tingkat kelas curah hujan sebesar $1500-2000 \mathrm{~mm} /$ thn. Sedangkan daerah yang sangat kering dengan tingkat kelas curah hujan sebesar $<1500 \mathrm{~mm} / \mathrm{thn}$ (Gambar 9). Maka dari itu daerah Kabupaten Gowa ini termasuk memiliki tingkat kelas curah hujan tahunan tingkat sedang sangat luas dibandingkan dengan daerah yang kering dan sangat kering

\subsection{Curah Hujan Bulanan}

Pada curah hujan bulanan di Kabupaten Gowa sendiri memperlihatkan bahwa adanya pembagian 4 kelas tingkat curah hujan bulanan yang di mana daerah terluas dengan tingkat curah hujan bulanannya paling tinggi yaitu sebesar $70-80 \mathrm{~mm} / \mathrm{bln}$, dan yang kedua memiliki tingkat curah hujan bulanan yang tinggi yaitu sebesar $60-70 \mathrm{~mm} / \mathrm{bln}$, dan memiliki tingkat curah hujan bulanan yang sedang yaitu antara 50-60 mm/bln, dan terakhir memiliki tingkat curah hujan bulanan yang sangat rendah yaitu $<50 \mathrm{~mm} /$ bln, maka dengan ini di Kabupaten Gowa memiliki tingkat kelas curah hujan Paling tinggi antara 70-80 mm/bln dengan daerah cakupan paling luas di bandingkan dengan daerah yang memiliki tingkat kelas curah hujan bulanan yang tinggi sedang maupun rendah seperti pada yang ditunjukkan Gambar 10. 


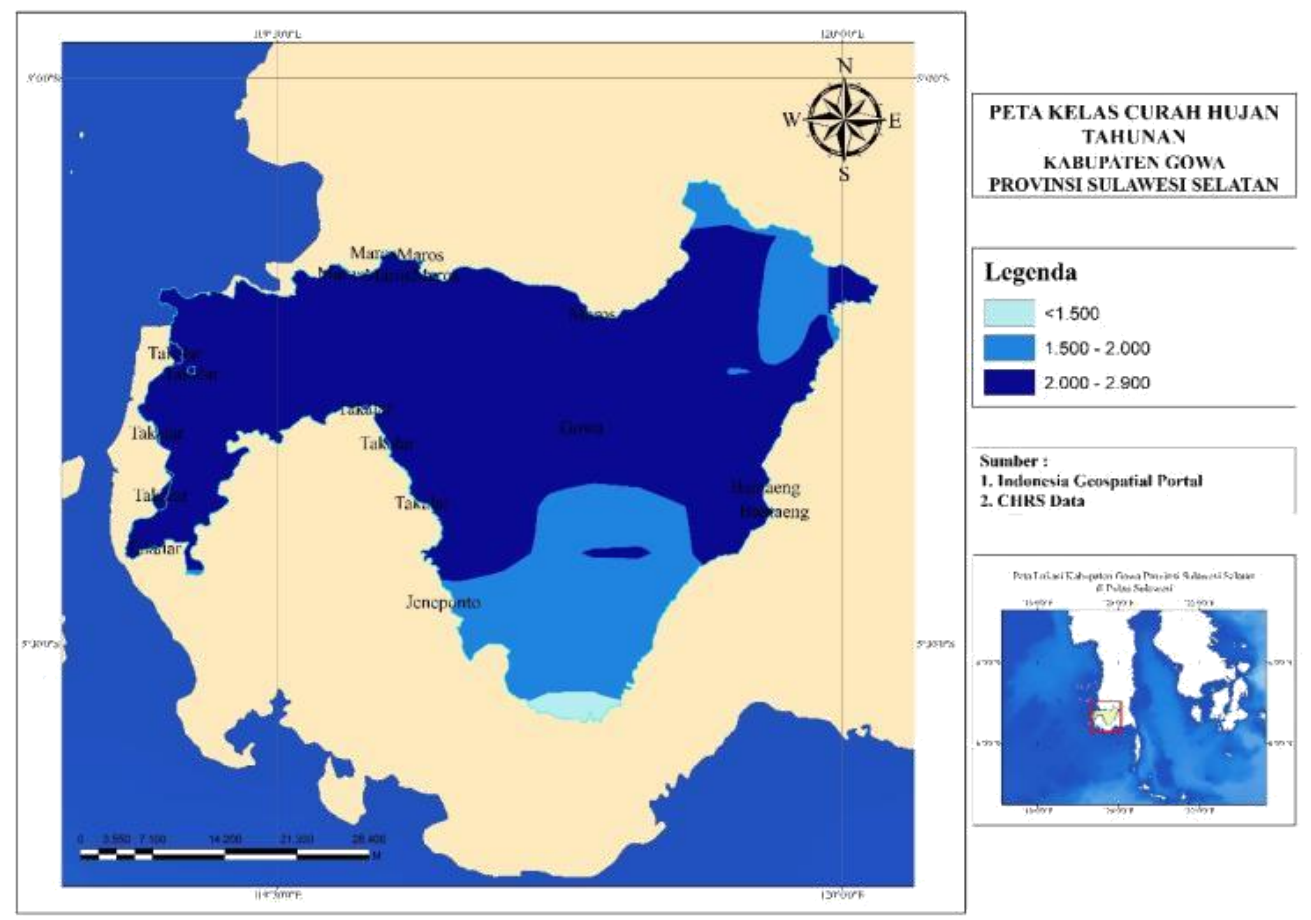

Gambar 9. Peta Curah Hujan Tahunan Kabupaten Gowa sebagai daerah penelitian Analysis Index Overlay untuk Pemetaan Kawasan Berpotensi Banjir Berbasis SIG

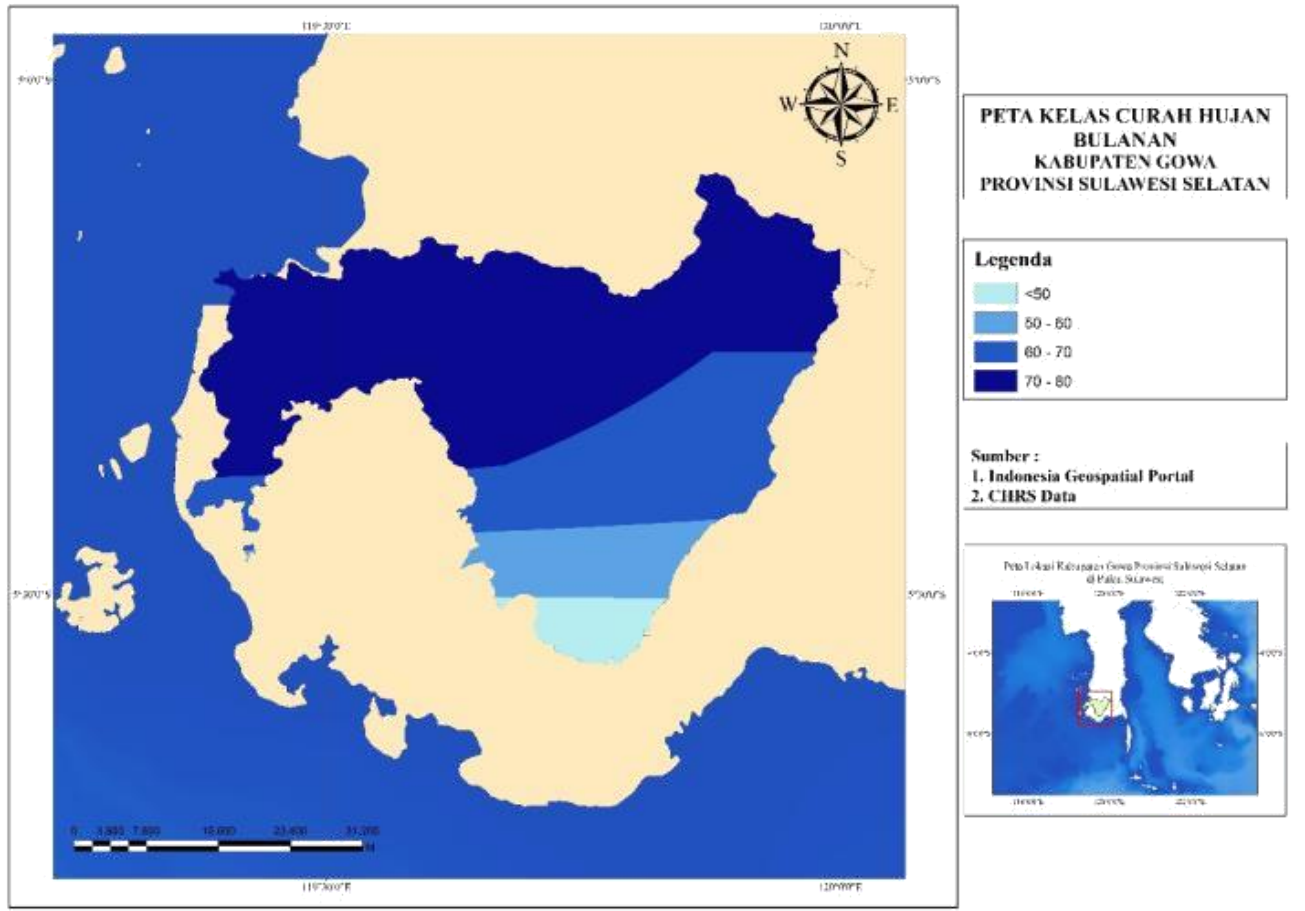

Gambar 10. Peta Curah Hujan Bulanan Kabupaten Gowa sebagai daerah penelitian Analysis Index Overlay untuk Pemetaan Kawasan Berpotensi Banjir Berbasis SIG

\subsection{Kejadian Banjir dan Hubungannya dengan Peta Rawan Banjir}

Peta kelas rawan banjir dihasilkan dari overlay beberapa parameter yang telah dibuat dengan melakukan pembobotan 2, peta kelas rawan banjir tersebut dibagi menjadi tiga kelas yaitu cukup rawan, rawan dan sangat rawan, namun pada peta ini daerah cukup rawan memiliki daerah yang lebih kecil dan daerah sangat rawan lebih meluas dan tersebar di hampir seluruh Kabupaten Gowa. Untuk karakteristik pada daerah cukup rawan terdiri dari tutupan lahan berupa lading sawah dan semak, dengan drainase bauk hingga buruk dengan lereng $0-15 \%$, untuk kelas rawan tutupan lahannya merupakan hutan sawah, semak dan lading, dengan kelerengan $0-30 \%$. Sedangkan pada daerah rawan 


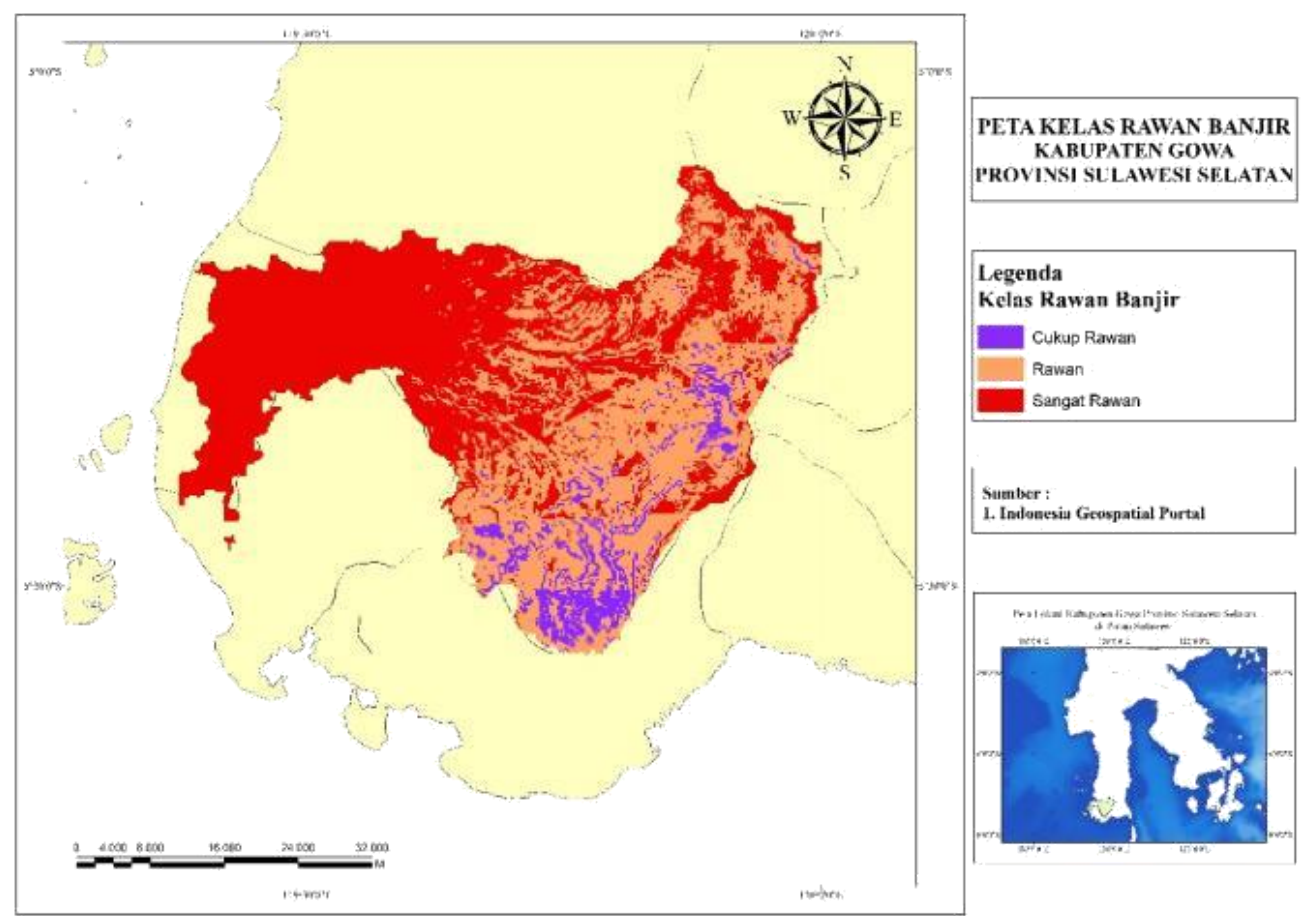

Gambar 11. Peta Kelas Rawan Banjir Kabupaten Gowa sebagai daerah penelitian Analysis Index Overlay untuk Pemetaan Kawasan Berpotensi Banjir Berbasis SIG.

tutupan lahannya merupakan sawah, pemukiman, hutan, lading hingga danau. Dengan kelerengan yang didominasi oleh $0-5 \%$ dan kelas drainasenya buruk hingga sedang.

Dari peta kelas rawan banjir tersebut terlihat bahwa daerah yang memiliki tingkat kerentanan akan banjir merupakan daerah barat dari Kabupaten Gowa yang terdiri dari Kecamatan Bontonompo, Kecamatan Bontonompo Selatan, Kecamatan Bajeng, Kecamatan Barombong, Kecamatan Pallangga, Kecamatan Somba Opu, Kecamatan Bontomrannu, Kecamatan Pattalasang, Kecamatan Parangloe, Kecamatan Manuju, Kecamatan Bungaya. Kerawanan banjir didapatkan melalui proses pembobotan dan scoring pada tiap parameter kerawanan banjir. Dalam penelitian ini, pembobotan parameter kerawanan banjir dapat dilihat pada Tabel 7.

Tabel 7. Bobot Parameter Kerawanan Banjir (Suherlan, 2001)

\begin{tabular}{clc}
\hline No & Kriteria & Bobot \\
\hline 1 & Curah Hujan & $30 \%$ \\
2 & Kemiringan Lereng & $20 \%$ \\
3 & Ketinggian & $30 \%$ \\
4 & Penutupan Lahan & $10 \%$ \\
5 & Tekstur Tanah & $10 \%$ \\
\hline
\end{tabular}

Berdasarkan tabel 7, parameter yang memiliki bobot tertinggi adalah curah hujan dan ketinggian yaitu sebesar $30 \%$. Sehingga dapat disimpulkan bahwa parameter yang paling dominan adalah curah hujan dan ketinggian di mana dari peta kelas rawan banjir yang didapat daerah yang sangat rawan merupakan daerah dataran rendah dengan drainase antara buruk hingga sangat buruk. Pada daerah penelitian kabupaten Gowa diketahui bahwa rata-rata potensi banjir disebabkan oleh hujan lebat terutama di dataran rendah sebagaimana pada penelitian yang dilakukan Putra (2019) sebelumnya yaitu kerawanan banjir Kabupaten Demak yang rata-rata disebabkan oleh luapan sungai dan banjir kiriman dari aliran lain melalui aliran sungai saat terjadi hujan deras karena parameter dengan bobot tertinggi yaitu kerapatan sungai $37 \%$, jarak sungai $29 \%$ dan curah hujan 18\%. Pada tahun 2019 diberitakan pada media detik.com daerah tersebut mengalami banjir akibat dari meluapnya Bendungan Bili-Bili dan Sungai Jeneberang karena hujan selama dua hari secara terus menerus, akibat dari daerah sangat rawan banjir merupakan sawah dan pemukiman, maka selain kerugian materi banjir ini juga menelan korban jiwa.

\section{KESIMPULAN}

Kabupaten Gowa, Provinsi Sulawesi Selatan dapat dikategorikan sebagai daerah rawan banjir, khususnya pada bagian barat dari Kabupaten Gowa. Hasil penelitian ini menunjukkan bahwa karakteristik daerah rawan banjir di Kabupaten Gowa adalah kelas lereng datar, dengan kelas drainase buruk-sangat buruk, kemudian tutupan lahan merupakan sawah dan juga pemukiman dengan curah hujan tahunan sebesar 2000-2900 $\mathrm{mm} / \mathrm{thn}$. Diharapkan setelah mengetahui kondisi ini nantinya dapat dilakukan upaya pencegahan bencana banjir di daerah tersebut.

\section{UCAPAN TERIMA KASIH}

Penulis menyadari bahwa dalam menyelesaikan artikel ini tidak lepas dari bantuan berbagai pihak. Pada kesempatan ini, penulis menyampaikan 
ucapan terima kasih kepada semua pihak yang sudah terlibat di dalam proses pembuatan artikel ini terutama kepada dosen pembimbing.

\section{DAFTAR PUSTAKA}

Badan Meteorologi Klimatologi Geofisika. (2013). Analisis hujan Bulan Januari 2013. Buletin $B M K G$.

Badan Nasional Penanggulangan Bencana. (2013). Bencana di Indonesia 2012.

Bisnis Indonesia. (2012). 13 Sungai di Jakarta Berpotensi Banjir. Handbook edisi 21 November 2012.

Darmawan, K., \& Suprayogi, A. (2017). Analisis Tingkat Kerawanan Banjir Di Kabupaten Sampang Menggunakan Metode Overlay Dengan Scoring Berbasis Sistem Informasi Geografis. Jurnal Geodesi Undip, 6, 31-40.

Junedi, H. (2010). Perubahan Sifat Fisika Ultisol Akibat Konversi Hutan Menjadi Lahan Pertanian. Jurnal Hidrolitan, 1: 10-14.

Kodoatie, Robert, J., \& Roestam, S. (2006). Pengelolaan Bencana Terpadu. Jakarta, Penerbit Yarsif Watampone.

Linsley, R. K., Kohler, M. A., \& Paulhus, J. L. (1975). Hydrology for Engineers. Tokyo, Mc Graw Hill Kogakusha Ltd.

Malingreau, J. (1977). Apropose Land Cover/ Land Use Classification And its Use With Remote Sensing Data in Indonesia. The Indonesian journal of Geography,7. 6-7.

Manongga, D., Papilaya, S., \& Pandie, S. (2010). Sistem Informasi Geografis Untuk Perjalanan Wisata di Kota Semarang. Jurnal Informatika, 10, 1-9.

Martha, A. (2011). Pemetaan Kawasan Berpotensi Banjir Menggunakan Sistem Informasi
Georafis (Studi Kasus Kabupaten Indramayu, Jawa Barat). Skripsi. Departemen IImu Tanah Dan Sumberdaya Lahan Fakultas Pertanian, Institut Pertanian Bogor

Matondang, J. P. (2013). Analisis Zonasi Daerah Rentan Banjir Dengan Pemanfaatan Sistem Informasi Geografis. Skripsi. Program Studi Teknik Geodesi Universitas Diponegoro; Semarang.

Putra, D. B., Suprayogi, A., \& Sudarsono, B. (2019). Analisis Kerawanan Banjir pada Kawasan Terbangun berdasarkan Klasifikasi Indeks EBBI (Enhanced Built-Up and Bareness Index) Menggunakan SIG (Studi Kasus di Kabupaten Demak). Jurnal Geodesi Undip, 8, 93-102.

Rai, K., \& Bhushan, N. (2004). Strategic Decision Making, (Analythic Hierarchy Process). diakses 3 Februari 2020 dari http://www.springer.com/9781-85233-756-8

Suhardiman. (2012). Zonasi Tingkat Kerawanan Banjir dengan Sistem Informasi Geografis (SIG) pada Sub DAS Walanae Hilir. Jurnal Penelitian Program Studi Keteknikan Pertanian Jurusan Teknologi Pertanian Fakultas Pertanian Universitas Hasanuddin.3,2.

Suherlan, E. (2001). Zonasi Tingkat Kerentanan Banjir Kabupaten Bandung Menggunakan System Informasi Geografis. Skripsi. Jurusan Geofisika Dan Meteorology. Institute Pertanian Bogor

Weng, Q. (2010). Remote sensing and GIS Integration: Theoris, Methods and Application. United States, McGraw-Hill Companies Inc. 